\title{
MYOCARDITIS AND CROUP CAUSED BY COXSACKIE VIRUS TYPE B5
}

\author{
BY \\ JUDITH M. BABB, MARGARET E. R. STONEMAN and H. STERN \\ From the Department of Paediatrics, St. George's Hospital and the Victoria Hospital for Children, \\ and the Department of Virology, St. George's Hospital Medical School, London
}

(RECEIVED FOR PUBLICATION FEBRUARY 7, 1961)

Myocarditis has long been recognized as a complication of rheumatic fever, diphtheria, scarlet fever and whooping cough. It also occurs in association with poliomyelitis and more rarely with other virus infections such as influenza, mumps, psittacosis, infectious mononucleosis, primary atypical pneumonia, varicella, measles, infectious hepatitis and yellow fever (Lyon, 1956; Silber, 1958). Myocarditis has also been described as occurring without evidence of such primary disease and has then been labelled variously as Fiedler's, idiopathic, interstitial, isolated or aseptic myocarditis.

The association of myocarditis and pericarditis with epidemic pleurodynia was reported by Bing (1933) and Heckscher (1933). This disease was subsequently shown to be caused by infection with the Coxsackie group B viruses (Curnen, Shaw and Melnick, 1949). More recently these viruses have been incriminated as a cause of aseptic myocarditis in newborn infants and myocarditis and pericarditis in both children and adults.

In the newborn infant Coxsackie infections are usually severe and commonly fatal. The disease is generalized and the predominant lesion in most cases is cardiac, although many infants also show lesions in the central nervous system, liver, adrenals and other tissues. Outbreaks of neonatal myocarditis have occurred in maternity homes and nurseries at times of prevalence of Coxsackie infection in the general population. These have been reported from Johannesburg (Gear and Measroch, 1953; Javett, Heymann, Mundel, Pepler, Lurie, Gear, Measroch and Kirsch, 1956; Gear, 1958), Cape Town (Suckling and Vogelpoel, 1958; Simenhoff and Uys, 1958; Naudé, Selzer and Kipps, 1958; Kipps, Naudé, Don and Cooper, 1958), Southern Rhodesia (Montgomery, Gear, Prinsloo, Kahn and Kirsch, 1955), Amsterdam (Dekking, 1955; van Creveld and de Jager, 1956; Verlinde, van Tongeren and Kret, 1956), Czechoslovakia (Vanek, Lukes, Potuznik, Polodnikova and Vilim,
1959; Lukes, 1959) and Hungary (Dömök, Molnár and Rudnai, 1960). A similar outbreak but without virus confirmation occurred in a newborn nursery in Melbourne (French, 1953). Sporadic cases have been reported from the United States (Kibrick and Benirschke, 1956, 1958a; 1958b; Sabin, 1957; Benirschke, Kibrick and Craig, 1958; Benirschke and Pendleton, 1958; Newton and Hosier, 1958; Hosier and Newton, 1958; Sprunt, 1958; Sussman, Strauss and Hodes, 1959; Rapmund, Gauld, Rogers and Holmes, 1959; Moossy and Geer, 1960; Brown, Lenz and Agate, 1960; Woodward, McCrumb, Carey and Togo, 1960), Hawaii (Delaney and Fukunaga, 1958), the Transvaal (Gear, Measroch and Prinsloo, 1956) and Australia (Jack, 1958).

There have been fewer reports of myocarditis caused by Coxsackie group B viruses in older children and the disease has usually been less severe than in the newborn infant (McLean, Croft, Prince and Heckmann, 1957; Varcasia and Castelli, 1957; Kagan and Bernkopf, 1957; Hosier and Newton, 1958; McLean, Walker and McNaughton, 1960). Many of the older children present with pericarditis (Kagan and Bernkopf, 1957; McLean, Walker and Bain, 1958; Walker, McNaughton and McLean, 1959; Gordon, Lennette and Sandrock, 1959; Brodie and Marchessault, 1960; Woodward et al., 1960), but this may be associated with clinical evidence of myocardial involvement (Kagan and Bernkopf, 1957).

In adults pericarditis has been the usual manifestation (Weinstein, 1957; Fletcher and Brennan, 1957, 1958; Movitt, Lennette, Mangum, Berk and Bowman, 1958; Bell and Meis, 1959; Gillett, 1959; Roberts, Lydon and MacIntosh, 1959; Sode and Baker, 1959; Woodward et al., 1960) and some cases, as in children, have shown clinical evidence of severe myocardial damage (Null and Castle, 1959; Woodward et al., 1960).

Coxsackie group A viruses may also be a cause of heart disease. Infection with these has been reported 
in several cases of myocarditis in small children (Archetti and Bortolozzi, 1954; Hosier and Newton, 1958; de Góes, de Paola, Bruno-Lobo and Dias, 1959) and in a case of pericarditis in an adult (Movitt et al., 1958).

Acute laryngo-tracheo-bronchitis or croup is of multiple aetiology. Most cases are caused by viruses, including influenza type $A$ and the three parainfluenza viruses (Vargosko, Chanock, Huebner, Luckey, Kim, Cumming and Parrott, 1959) and Echo virus type 11 (Philipson and Wesslén, 1958). Apart from a mention that Coxsackie A9 may be a cause (Forbes, 1960) the Coxsackie viruses have not been incriminated so far in this type of respiratory infection.

During 1960 Coxsackie B infections were common in London (Stern, 1961). In the present paper four cases of severe infection in small children are described, two with myocarditis, one with myocarditis and croup and one with croup alone.

\section{Virus Techniques}

Virus Isolation. Throat swabs and faeces were dealt with at once or kept at $-70^{\circ} \mathrm{C}$. for 24 hours. The former were thoroughly rubbed into $1 \mathrm{ml}$. of Hanks' saline containing 500 units of penicillin, $200 \mu \mathrm{g}$. of streptomycin and 50 units of mycostatin per $\mathrm{ml}$. and then spun at 2,000 r.p.m. for 15 minutes. Faecal specimens were emulsified with the Hanks' saline to make a $20 \%$ suspension and centrifuged at 4,000 r.p.m. for 30 minutes. Six tubes, comprising two Hela, two human primary amnion and two Rhesus monkey tissue cultures, were each inoculated with $0.2 \mathrm{ml}$. of supernatant from the treated throat swab or faeces. They were incubated at $37^{\circ} \mathrm{C}$. for two hours and the fluid of each tube was then replaced with fresh medium. The tubes were examined microscopically for cytopathic changes daily for $\mathbf{1 4}$ days. In positive cases the fluid was removed and the virus identified by neutralization tests, usually in the type of tissue culture in which it was isolated.

The isolate was diluted one in 100 and mixed with equal volumes of antisera for each of the Coxsackie viruses B1 to 5 and $A 9$, as well as with pools containing respectively all six Coxsackie antisera and the polio antisera. Antisera were prepared by hyperimmunization of rabbits and each serum was used at a dilution equivalent to 20 antibody units per $0.1 \mathrm{ml}$. The mixtures were kept at $37^{\circ} \mathrm{C}$. for two hours and $0.2 \mathrm{ml}$. of each was inoculated into duplicate tissue culture tubes. A virus titration was included with each test. The results were read when the control tubes showed 4-plus cytopathic changes, usually within two to three days. When the results were equivocal because of excess virus the test was repeated using approximately $100 \mathrm{TCD}_{50}$.

The monkey kidney cells were maintained on medium 199 containing $\mathrm{SV}_{5}$ antiserum, the Hela and amnion cells on Earle's saline with $0.5 \%$ lactalbumin hydrolysate and $5 \%$ inactivated horse serum. Refeeding of tubes was carried out at about five-day intervals and they were incubated without rolling.

Serology. Sera were obtained from patients during the acute and convalescent stages of illness and were stored at $-20^{\circ} \mathrm{C}$. until used. They were inactivated at $56^{\circ} \mathrm{C}$. for half-an-hour and the two sera from each patient were tested at the same time.

Complement fixation tests for antibodies against influenza, parainfluenza and adenoviruses were, carried out in tubes, using two units of complement, four units of antigen and overnight fixation at $4^{\circ} \mathrm{C}$. Neutralization tests were used for the detection of Coxsackie antibodies. These were carried out by mixing equal volumes of several dilutions of each serum and virus suspensions containing approximately $100 \mathrm{TCD}_{50}$ per $0.1 \mathrm{ml}$. They were kept at $37^{\circ} \mathrm{C}$. for two hours and $0.2 \mathrm{ml}$. of each mixture was inoculated into duplicate tissue culture tubes. The results were read when control virus tubes showed 4-plus degeneration, usually within three to four days. Antibody titres were expressed as the reciprocal of the highest initial dilution of serum producing full fixation of complement or complete virus neutralization.

Case 1. A male child, 19 months old, weighed $3 \mathrm{lb} .11 \mathrm{oz}$. at birth. He was born prematurely at 36 weeks after induction for maternal toxaemia. He had pneumonia at 2 months of age and recurrent attacks of bronchitis subsequently. Two weeks before admission he had a further attack of pneumonia, treated with antibiotics, and since then had been having repeated attacks of dyspnoea.

On examination he was pale and showed slight peripheral oedema. The temperature was $98 \cdot 6^{\circ} \mathrm{F}$. The pulse rate was $120 / \mathrm{min}$. and he had tic-tac heart sounds and a systolic murmur along the left sternal margin. The liver was enlarged to $3 \mathrm{~cm}$. below the costal margin. The chest was clear.

Investigations showed a haemoglobin of $8 \mathrm{~g} . / 100 \mathrm{ml}$. and a white cell count of 8,400 with $38 \%$ neutrophils, $55 \%$ lymphocytes, $5 \%$ monocytes, $1 \%$ eosinophils and $1 \%$ basophils. The red cells were hypochromic with anisocytosis. The cold agglutinin and tuberculin skin tests were negative. A radiograph of the chest showed slight enlargement of the heart shadow. An electrocardiogram was normal. Phonocardiographic examination, three weeks after admission, demonstrated only physiological splitting of the second sound and a loud third sound. Faeces were examined for virus only three weeks after admission and no isolations were made. Serum specimens were obtained after the second and fifth weeks in hospital; both showed titres of more than 500 of Coxsackie B5 antibody. Antibodies against the other Coxsackie B viruses were all $<5$ in titre. The child had been vaccinated against poliomyelitis and low levels of antibodies for the three types were present.

$\mathrm{He}$ was treated with iron and one month later the haemoglobin level was $12.3 \mathrm{~g} . / 100 \mathrm{ml}$. One week after admission the signs of cardiac failure had disappeared and there were no further attacks of dyspnoea. He had 
a mild attack of bronchitis two weeks later and a swab showed only normal bacterial flora. He was discharged five weeks after admission apparently well. Four months after the onset of his illness an apical systolic murmur was still present, but there were no signs of cardiac failure.

Eleven days after the child returned home his mother was admitted to hospital with aseptic meningitis and two days later his father and aunt, who lived in the same house, were also admitted with the same illness. Poliovirus type 3 was isolated from the mother's faeces and both parents showed high levels of polio type 3 antibody during convalescence. In both, Coxsackie B5 antibody was present at a titre of 5 .

Case 2. The child, a male, weighed $5 \mathrm{lb} .2 \mathrm{oz}$. at birth. He was born at full term by normal delivery. He had always been difficult to feed, but was otherwise well until the age of 9 months when he was referred to hospital mainly on account of pallor.

On examination he was pale and had slight oedema of the legs. The temperature was $98 \cdot 4^{\circ} \mathrm{F}$. His pulse rate was $140 / \mathrm{min}$. and he had tic-tac heart sounds and a systolic murmur at all areas of the praecordium and conducted into the axilla. The liver was enlarged to $3 \mathrm{~cm}$. below the costal margin. The chest was clear.

Investigations showed a haemoglobin of $10.8 \mathrm{~g} . /$ $100 \mathrm{ml}$. and a white cell count of 12,400 with $21 \%$ neutrophils, $68 \%$ lymphocytes, $7 \%$ monocytes and $4 \%$ eosinophils. The red cells were slightly microcytic and hypochromic. The E.S.R. was $5 \mathrm{~mm}$. in the first hour and the cold agglutinin test was negative. A radiograph of the chest and an electrocardiogram were both normal. A phonocardiogram demonstrated a mid-diastolic as well as a systolic murmur of ejection type. Coxsackie B5 was isolated from the faeces and the homologous antibody increased in titre from 5 to 100 during the course of illness.

He was treated with iron which increased his haemoglobin to $12 \mathrm{~g} . / 100 \mathrm{ml}$. after three weeks. Two weeks after admission he became pyrexial and had a slightly injected throat, but this cleared in four days without treatment. The signs of heart failure disappeared and he was discharged after one month in hospital. He still had a slight systolic murmur five months later.

Case 3. The infant, a 4-month-old male, weighed $5 \mathrm{lb} .6 \mathrm{oz}$. at birth. He was born prematurely at 36 weeks by caesarian section because of antepartum haemorrhage and was nursed for three days in an incubator. He made normal progress until one week before admission to hospital, when, after a second dose of triple antigen, he became lethargic. Three days later he became pyrexial and was diagnosed by his local doctor as a case of acute tonsillitis and treated with penicillin. For 24 hours before admission there had been anorexia and almost continuous screaming. His 3-year-old brother and parents were well.

On examination, he was a screaming, miserable, very pale child with conjunctivitis and injected fauces. The temperature was $102^{\circ} \mathrm{F}$. The pulse rate was $170 / \mathrm{min}$. and he had a blowing systolic murmur at all areas of the praecordium which was transmitted through to the back. The liver was enlarged to $3 \mathrm{~cm}$. below the costal margin. There was a positive Kernig's sign but no neck stiffness.

The following day his condition was worse with marked respiratory stridor and apparently some difficulty in swallowing. There was oedema of the retropharyngeal space and enlarged glands in the left posterior triangle.

Laboratory investigations showed a haemoglobin of 8.6 g. $/ 100 \mathrm{ml}$., a white cell count of 13,300 with $48 \%$ neutrophils and $52 \%$ lymphocytes, a normal urine and cerebrospinal fluid and a negative Paul-Bunnell test. A radiograph of the chest was normal. Bacteriological examination of throat and eye swabs and faeces showed only normal flora. Coxsackie virus type B5 was isolated from the throat swab. Type B5 antibodies increased in titre during the course of the illness from five to 50 . Antibodies against influenza viruses types $\mathbf{A}, \mathbf{B}$ and $\mathbf{C}$, parainfluenza viruses types 1,2 and 3 and adenoviruses were absent.

The infant was treated with oxygen, humidity and tetracycline, and improved rapidly. An electrocardiogram on the eleventh day after admission was normal. The heart murmur became softer and by the twelfth day had disappeared. He was apparently completely well on discharge and again five months later.

Case 4. A male infant, aged 4 months, weighed $7 \mathrm{lb} .12 \mathrm{oz}$. at birth. He was born by low forceps delivery and made normal progress until 12 weeks before admission when he developed a spasmodic cough which was worse at night. He produced mucoid sputum, but there was no whooping or vomiting. Soon after developing the cough he became obviously wheezy.

On examination his temperature was $99 \cdot 4^{\circ} \mathrm{F}$. There was marked inspiratory stridor. The tonsils and posterior pharyngeal wall were injected and the former were covered with patchy exudate. The cervical glands were bilaterally enlarged. The heart sounds were normal and the chest was clear. The liver was slightly enlarged.

The haemoglobin was $13 \cdot 1 \mathrm{~g} . / 100 \mathrm{ml}$. and the white cell count was 10,900 with $28 \%$ neutrophils, $64 \%$ lymphocytes, $6 \%$ monocytes and $2 \%$ eosinophils. Radiograph of the chest was normal. Bacteriological examination of the throat showed only normal flora. Coxsackie B5 was isolated from the faeces. An acute serum specimen was not taken, but a specimen collected on the 14th day showed a Coxsackie B5 antibody titre of 50. Antibodies were absent against influenza types $A, B$ and $C$, parainfluenza types 1, 2 and 3 and adenoviruses.

He was treated with oxygen, humidity and tetracycline. Despite this, four days after admission, his condition deteriorated and he showed extreme respiratory distress. There was severe stridor, with suprasternal and intercostal recession with poor entry and the pulse rate had increased to $140 / \mathrm{min}$. A tracheotomy was performed and laryngoscopy showed slightly injected and oedematous vocal cords. He improved rapidly and had been well since, but oedema of his larynx has persisted and after 
three months it has not been possible to close his tracheotomy.

\section{Discussion}

The majority of cases of aseptic myocarditis which have been reported since the original observations of Fiedler (1899) and Zuppinger (1901) have been within the age range of 3 months to 3 years: Saphir and Cohen (1957) reviewed 90 cases which came to autopsy after 1948 and showed that $71 \%$ were under 1 year old. Although the disease tends to be less severe in older children than in newborn infants, epidemics have been described in older children which have carried a high mortality (Stoeber, 1952; Choremis, Cassimos, Nihoyannopoulos, Mavrou and Haka, 1956; Freundlich, Berkowitz, Elkon and Wilder, 1958). The present paper shows that at least a proportion of the cases of myocarditis in older children is caused by Coxsackie group $B$ viruses.

The first two cases in the present series were very similar in their clinical features, although their manner of onset was different. Case 1 presented with paroxysmal dyspnoea after a respiratory infection, whereas Case 2 was referred to the outpatient department owing to pallor. On examination both were pale and showed cardiac failure with peripheral oedema, tachycardia, systolic murmurs and liver enlargement. The degree of anaemia in Case 1 was at first thought to be sufficient to account for the cardiac failure. However, when the second case was observed with the same features, but only mild anaemia, the diagnosis of virus myocarditis was considered and later confirmed by virus studies.

These two children resembled in their clinical features other reported cases of Coxsackie B myocarditis of older children. Varcasia and Castelli (1957) described a $2 \frac{1}{2}$-year-old boy also with a B5 infection. He presented with dyspnoea and pallor accompanying an upper respiratory infection and examination showed mild anaemia and cardiac failure including cardiac enlargement and a transient systolic murmur. Myocardial involvement was confirmed by electrocardiographic changes. Followup studies were not available. The 5-year-old boy reported by both McLean et al. (1957) and Hosier and Newton (1958), with Coxsackie B2 infection, had signs of cardiac failure two weeks after an upper respiratory illness. Gross cardiac enlargement was demonstrated radiologically and his electrocardiographic changes were compatible with myocarditis. He had two relapses during the course of his illness and the cardiomegaly persisted for at least 10 months.

Kagan and Bernkopf reported a more severe. infection in a 10-month-old girl. She was very ill with cyanosis and severe pallor and evidence of gross cardiac failure. A large pericardial effusion developed and Coxsackie B3 was isolated both from the effusion and faeces. Cardiac enlargement persisted despite aspiration of the pericardial fluid, but recovery was complete after 43 days. They observed 12 other cases of acute myocarditis during the same period. These, aged 5 months to 9 years, had similarly severe degrees of cardiac failure and five of the children died; virus was isolated from the myocardium of two of them. The 7-week-old infant also reported by Hosier and Newton died after a fulminating course similar to that occurring in newborn infants.

The third case of the present group was admitted to hospital with acute respiratory infection. On examination he was found to have signs of cardiac failure. Twenty-four hours later he developed laryngeal stridor. In Case 4 severe laryngeal stridor necessitating tracheotomy was the main symptom. These appear to be the first reported cases of croup caused by Coxsackie B viruses. The association of croup with myocarditis was previously recorded by Saphir (1945), although virus studies were not available; five children, aged 11 months to 7 years, died despite tracheotomy and the cause of death was considered to have been the severe myocarditis demonstrated at autopsy.

The absence of electrocardiographic changes in the present cases of myocarditis was possibly due to examination in the later stages of illness. Absence of such changes, however, does not exclude myocarditis (Fox and Overstreet, 1941; Lyon, 1956; Delaney and Fukunaga, 1958). The final prognosis is unknown. Cases 1 and 2 showed persistent heart murmurs four and five months later. Repair of the damaged myocardium in neonatal cases is by fibrosis (Simenhoff and Uys, 1958) and it is uncertain what part the fibrous lesions may play in heart disease in later life.

With the increasing use of routine virological investigations it is likely that the aetiology of more cases of aseptic myocarditis will be discovered. All members of the enterovirus group can probably cause cardiac damage. Both group $\mathbf{A}$ and group $\mathbf{B}$ Coxsackie viruses have now been shown to be capable of doing so and the polio viruses have long been recognized as a cause of myocarditis in a high proportion of cases of paralytic poliomyelitis (Nordenstam, 1956; Bengtsson and Nordenstam, 1956). The demonstration of electrocardiographic changes during an epidemic of aseptic meningitis caused by Echo virus type 9 (von Olderhausen, 1957) suggests that the Echo viruses may also be responsible for some cases of myocarditis. 


\section{Summary}

Previous reports of myocarditis due to Coxsackie virus infections are briefly reviewed.

Four cases are described of Coxsackie virus B5 infection in children aged 4 to 19 months. These occurred during a period of prevalence of Coxsackie infection in the general population. Two of the cases had clinical evidence of acute myocarditis, one of myocarditis with croup, and the fourth of croup alone. All the patients recovered.

The two children with croup are, we believe, the first reported cases of croup due to Coxsackie virus infection.

We would like to thank Dr. Ursula James of the Victoria Hospital for Children for allowing us to publish her cases and for her helpful advice and criticism. We are also grateful to Professor S. D. Elek of St. George's Hospital for his advice on the virological details.

\section{REFERENCES}

Archetti, I. and Bortolozzi, M. (1954). Un virus del tipo Coxsackie isolato durante un'epidemia clinicamente non precisata. (Nota isolato durante un'epidemia clinicamente non precisata.
preliminare.) R.C. Ist. sup. Sanità (Roma), 17, 999.

Bell, J. F. and Meis, A. (1959). Pericarditis in infection due to Coxsackie virus group B, type 3. New Engl.J. Med., 261, 126.

Bengtsson, E. and Nordenstam, H. (1956). The poliomyelitis epidemic in Stockholm, 1953. XV. Cardiovascular complications in fatal cases of poliomyelitis. Acta med. scand., Suppl. 316,95 .

Benirschke, K., Kibrick, S. and Craig, J. M. (1958). The pathology of fatal Coxsackie infection in the newborn. Amer. J. Path., 34, 587.

and Pendleton, M. E. (1958). Coxsackie virus infection. An important complication of pregnancy. Obstet. and Gynec., 12, 305.

Bing, H. I. (1933). Epidemical pericarditis. Acta med. scand., $80,29$.

Brodie, H. R. and Marchessault, V. (1960). Acute benign pericarditis caused by Coxsackie virus group B. New Engl.J. Med., 262, 1278 .

Brown, G. C., Lenz, W. R. and Agate, G. H. (1960). Laboratory data on the Detroit poliomyelitis epidemic-1958. J. Amer. med. Ass., 172, 807.

Choremis, C., Cassimos, Ch., Nihoyannopoulos, J., Mavrou, K. and Haka, C. (1956). Idiopathic myocarditis of the Fiedler type. Ann. paediat. (Basel), 187, 444.

van Creveld, S. and de Jager, H. (1956). Myocarditis in newborns caused by Coxsackie virus. Clinical and pathological data. Ibid., 187, 100.

Curnen, E. C., Shaw, E. W. and Melnick, J. L. (1949). Disease resembling nonparalytic poliomyelitis associated with a virus pathogenic for infant mice. J. Amer. med. Ass., 141, 894.

de Góes, P., de Paola, D., Bruno-Lobo, M. and Dias, L. D. (1959). Miocardite por vírus Coxsackie do grupo A. An. Microbiol. (rio de J.) 7,13 .

Dekking, F. (1955). Myocarditis bij zuigelingen veroorzaakt door het Coxsackie virus type B. Ned. T. Geneesk, 99, 2676.

Delaney, T. B. and Fukunaga, F. H. (1958). Myocarditis in a newborn infant with encephalomeningitis due to Coxsackie virus group B, type 5. New Engl. J. Med., 259, 234.

Dömök, I., Molnár, E. and Rudnai, O. (1960). An epidemic of Bornholm's disease in Hungary in 1958. Acta microbiol. Acad. Sci. hung., 7, 151.

Fiedler, A. (1899). Ueber akute interstitielle myokarditis. Festschr. der Stadkrankenh. Dresden Friedrichstadt; part 2, 3.

Fletcher, E. and Brennan, C. F. (1957). Cardiac complications of Coxsackie-virus infection. Lancet, 1, 913. (1958). Cardiac complications of Coxsackie-virus infection. Ibid., $2,585$.

Forbes, J. A. (1960). C'roup viruses: clinical aspects. Med. J. Aust., 2, 769.

Fox, I. R. and Overstreet, R. M. (1941). Isolated myocarditis: report of a case. Northw. Med. (Seattle), 40, 89.

French, E. L. (1953). Personal communication. Quoted by Kibrick and Benirschke (1956)

Freundlich, E., Berkowitz, M., Elkon, A. and Wilder, A. (1958). Primary interstitial myocarditis. Report of an epidemic outbreak. Amer. J. Dis. Child., 96, 43.
Gear, J. H. S. (1958). Coxsackie virus infections of the newborn. In Progress in Medical Virology, ed. E. Berger and J. L. Melnick, vol. 1 , p. 106 . Karger, Basel. - and Measroch, V. (1953). S. Afr. Inst. med. Res. Ann. Rep. for 1952, p. 38 .

and Prinsloo, F. R. (1956). The medical and public 30, 806 .

Gillett, R. L. (1959). Acute benign pericarditis and the Coxsackie viruses. New Engl. J. Med., 261, 838.

Gordon, R. B., Lennette, E. H. and Sandrock, R. S. (1959). The varied clinical manifestations of Coxsackie virus infections: observations and comments on an outbreak in California. Arch. intern. Med., 103, 63.

Heckscher, H. (1933). Myositis epidemica-Sorositis. Acta med. scand., 80, 251.

Hosier, D. M. and Newton, W. A., Jr. (1958). Serious Coxsackie infection in infants and children. Amer. J. Dis. Child. 96, 251.

Jack. I. (1958). Personal communication. Quoted by Kibrick and Benirschke (1958b)

Javett, S. N., Heymann, S., Mundel, B., Pepler, W. J., Lurie, H. I., Gear, J., Measroch, V. and Kirsch, Z. (1956). Myocarditis in the newborn infant. A study of an outbreak associated with Coxsackie group B virus infection in a maternity home in Johannesburg. J. Pediat. 48, 1.

Kagan, H. and Bernkopf, H. (1957). Pericarditis caused by Coxsackie virus B. Ann. paediat. (Basel), 189, 44.

Kibrick, S. and Benirschke, K. (1956). Acute aseptic myocarditis and meningoencephalitis in the newborn child infected with Coxsackie virus group B, type 3. New Engl. J.-Med., 255, 883. - (1958a). Severe generalized disease in the newborn due to Coxsackie virus group B. Amer. J. Dis. Child., 96, 498.

-, - (1958b). Severe generalized disease (encephalohepatomyocarditis) occurring in the newborn period and due to infection with Coxsackie virus, group B. Evidence of intrauterine infecwith Coxsackie virus, group B. Evidence

Kipps, A., Naudé, W. du T. Don, P. and Cooper, E. D. (1958) Coxsackie virus myocarditis of the newborn. Epidemiological features. Med. Proc., 4, 401.

Lukes, J. (1959). Newborn myocarditis and meningoencephalitis of Coxsackie virus B3 origin. Ćsl. Pediat., 14, 731 .

Lyon, E. (1956). Virus Diseases and the Cardiovascular System. Grune and Stratton, New York and London.

McLean, D. M., Croft, C. C., Prince, J. T. and Heckmann, E. E. (1957). Coxsackie and Echo virus infections in Ohio during 1956." Ohio St. med. J., 53, 907.

, Walker, S. J. and Bain, H. W. (1958). Coxsackie B5 virus in association with pericarditis and pleurodynia. Canad. med. Ass. J., 79, 789.

- and McNaughton, G. A. (1960). Enterovirus infections in Toronto, 1959. Ibid., 82, 661.

Montgomery J Gear, J., Prinsloo, F. R., Kahn, M. and Kirsch, Z. G. (1955). Myocarditis of the newborn. An outbreak in a maternity home in Southern Rhodesia associated with Coxsackie group-B virus infection. S. Afr. med. J., 29, 608.

Moossy, J. and Geer, J. C. (1960). Encephalomyelitis, myocarditis and adrenal cortical necrosis in Coxsackie B3 virus infection. Distribution of the central nervous system lesions. Arch. Path. (Chicago), 70, 614.

Movitt, E. R. Lennette, E. H., Mangum, J. F., Berk, M. and Bowman, M. S. (1958). Acute benign pericarditis: report of two cases associated with group $\mathrm{A}$ and group $\mathrm{B}$ Coxsackie viruses. New Engl. J. Med., 258, 1082 .

Naudé, W. du T., Selzer, G. and Kipps, A. (1958). Coxsackie virus myocarditis of the newborn. Virus studies. Med. Proc., 4, 397.

Newton, W. A., Jr. and Hosier, D. M. (1958). Coxsackie infection in infants and children: focal and disseminated; fatal and nonfatal. Amer. J. Path., 34, 587.

Nordenstam, H. (1956). The poliomyelitis epidemic in Stockholm 1953. XIX. Patho-anatomical findings in 26 fatal cases of poliomyelitis. Acta med. scand., Suppl. 316, 114.

Null, F. C., Jr. and Castle, C. H. (1959). Adult pericarditis and myocarditis due to Coxsackie virus group B, type 5. New Engl. J. Med., 261, 937.

von Olderhausen, H.-F. (1957). Klinische Beobachtungen über eine neuartige primäre aseptische Meningoenzephalitis. Disch. med. Wschr., 82, 442.

Philipson, L. and Wesslén, E. (1958). Recovery of a cytopathogenic agent from patients with non-diphtheritic croup, and from daynursery children. I. Properties of the agent. Arch. ges. Virusforsch., 8, 77.

Rapmund, G., Gauld, J. R., Rogers, N. G. and Holmes, G. E. (1959). Neonatal myocarditis and meningoencephalitis due to Coxsackie virus group B, type 4 . Virologic study of a fatal case with simultaneous aseptic meningitis in the mother. New Engl. J. Med., $260,819$.

Roberts, R. Lydon, M. and MacIntosh, M. (1959). Coxsackie pericarditis. Canad. med. Ass. J., 80, 722.

Sabin A. (1957). Comment in Year Book of Pediatrics (1957-58 Year Book Series), ed. S. S. Gellis, p. 269. The Yearbook Publishers, Chicago. 
Saphir, O. (1945). Laryngeal edema, myocarditis and unexpected death (early acute laryngotracheobronchitis). Amer.J. med. Sci., 210, 296.

and Cohen, N. A. (1957). Myocarditis in infancy. A.M.A. Arch. Path., 64, 446.

Silber, E. N. (1958). Respiratory viruses and heart disease. Ann. intern. Med., 48, 228.

Simenhoff, M. L. and Uys, C. J. (1958). Coxsackie virus myocarditis of the newborn. A pathological survey of 4 cases. Med. Proc., 4, 389.

Sode, J. and Baker, W. J. (1959). Acute benign pericarditis and pneumonitis associated with Coxsackie virus group B, type 2, infection in a young man. Arch. intern. Med., 104, 313.

Sprunt, K. (1958). Personal communication. Quoted by Sussman et al. (1959).

Stern, H. (1961). Aetiology of central nervous system infections during period of prevalence of poliovirus and Coxsackie virus. Brit. med. J., 1, 1061 ,

Stoeber, E. (1952). Weitere Untersuchungen über epidemische Myocarditis ('Schwielenherz') des Säuglings. Z. Kinderheilk., 71, 319, 592.

Suckling, P. V. and Vogelpoel, L. (1958). Coxsackie myocarditis of the newborn. Med. Proc., 4, 372.

Sussman, M. L., Strauss, L. and Hodes, H. L. (1959). Fatal Coxsackie group B virus infection in the newborn. Amer. J. Dis. Child., 97, 483.
Vanek, J., Lukes, J., Potuznik, V., Polodnikova, I. and Vilim, V. (1959). Myocarditis and encephalitis in newborn infants caused by Coxsackie B virus. J. Hyg. Epidem. (Praha) 3, 283.

Varcasia, E. and Castelli, L. (1957). Su di un caso di miocardite da Coxsackie B5. R.C. Ist. sup. Sanità, 20, 831.

Vargosko, A. J., Chanock, R. M., Huebner, R. J., Luckey, A. H., Kim, H. W., Cumming, C. and Parrott, R. H. (1959). Association of type 2 hemadsorption (parainfluenza 1) virus and Asian influenza $\mathrm{A}$ virus with infectious croup. New Engl. J. Med., $261,1$.

Verlinde, J. D., van Tongeren, H. A. E. and Kret, A. (1956). Myocarditis in newborns due to group B Coxsackie virus. Virus

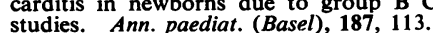

Walker, S. J., McNaughton, G. A. and McLean, D. M. (1959) Coxsackie B5 virus infections in children: Toronto, 1958. Canad. J. publ. Hlth, 50, 461.

Weinstein, S. B. (1957). Acute benign pericarditis associated with Coxsackie virus group B, type 5. New Engl. J. Med., 257, 265.

Woodward, T. E., McCrumb, F. R., Jr., Carey, T. N. and Togo, Y. (1960). Viral and rickettsial causes of cardiac disease, including the Coxsackie virus etiology of pericarditis and myocarditis. Ann. intern. Med., 53, 1130 .

Zuppinger (1901). Ueber Herztod bei anscheinend bedeutungslosen Oberflächlichen Geschwürsprocessen. Wien. klin. Wschr., 14, 799. 